\title{
Rural Farmers Households Livelihoods Security Options amidst Conflicts in Taraba State, Nigeria
}

\author{
Rukwe DT ${ }^{1 *}$, Oladimeji ED ${ }^{1}$ and Tsukutoda II2 \\ ${ }^{1}$ National Agricultural Extension and Research Liaison Services, Ahmadu Bello University, Zaria, Nigeria \\ 2Federal University Wukari, Taraba State, Nigeria
}

\section{*Corresponding Author}

Rukwe DT

\section{Article History}

Received: 22.10.2019

Accepted: 31.10 .2019

Published: 09.11.2019

\begin{abstract}
The study aim at assessing rural farmer's household's livelihood security options amidst conflicts in Taraba state, Nigeria. Specifically, the study was to identify Farmers' Alternative Livelihood activities and analyse the determinants of livelihood diversification strategies among rural households. Multi-stage sampling procedure was adopted in the process of sample selection. Primary data were collected using well structure questionnaire administered to 84 respondents, out of which 82 questionnaires were properly filled and returned. Descriptive statistical tools such as frequency, percentage and ranking and inferential statistics such as Logit regression were used to achieve objectives of the study. The result revealed that the major choice of alternative livelihood activities for most of the rural farmers in the Taraba State in the midst of conflicts (famers-herders and inter-tribal conflicts) were petty trading $(81.7 \%)$, casual daily labour $(62.2 \%)$, food vending (54.9\%) and Selling of firewood/Charcoal production (52.4\%). Determinants of household livelihood alternative activities amidst conflict were level of formal education $((p<0.01)$, insecurity $(p<0.01)$, farm size $(p<0.01)$, reduced farm income $(p<0.05)$, extension contact $(p<0.01)$ and dependency households $(p<0.01)$. it was concluded that was that farmers in conflicts affected area use diversify their income sources into non-farm activities to conserve livelihood security in the midst of conflicts. The study recommended Governmental and nongovernmental organizations should give attention for rural livelihood improvement through providing security in the conflicts areas.
\end{abstract}

Keywords: Farmers, conflicts, livelihood.

\section{INTRODUCTION}

Agriculture in Nigeria remains in the hand smallholder's farmers who dwelled mostly in the rural areas and their primary occupation is farming. In the rural communities, more than half of households are agricultural households implying that they depend on farming for household income and food supply. However, most rural households (97.6\%) are involved in crop farming which essentially contributes to household food and income supply [1]. However, this role of agriculture as a primary livelihood activity has been challenged in recent times as result of widespread and frequent occurrence of conflicts.

Conflicts threaten the livelihood of millions in developing countries like Nigeria, especially the very poor because it directly affects their livelihood sources. Diverse cultural systems, socioeconomic conditions, and environmental exposures make household's sources of income vulnerable over time [2]. Most Conflict such as farmers- herders, ethnic and communal conflicts in Nigeria emanated from increase competition over arable land use as a result of the increase in population which livelihood has adjusted to for years culminates in defenseless attack that threaten the sustainability of household income and food supply. Some livelihood assets such as agricultural production knowledge and tools become redundant, influencing sustainable livelihood strategies [3]. Amidst such cases, opportunities for livelihood diversification become critical in determining community and household ability to cope with conflicts period. Efforts to end the conflicts must therefore include livelihood diversification components to build resilience and lessen susceptibility especially among farmers. To achieve this, a broader understanding of the factors influencing and enabling livelihood decisions as well as the processes involved is needed [4].

Copyright @ 2019: This is an open-access article distributed under the terms of the Creative Commons Attribution license which permits unrestricted use, distribution, and reproduction in any medium for non commercial use (NonCommercial, or CC-BY-NC) provided the original author and source are credited. 
Conflicts through diverse stimuli and intervening factors affect economic, social, cultural, and natural conditions of individuals and communities, altering the value and usefulness of various livelihood assets. The frequent occurrence of conflicts and the resulting effect on agriculture have necessitated the adoption of alternative livelihoods opportunities among farmers in order to secure their livelihoods [5]. Conceptually, "livelihoods" connote the means, activities, entitlements, and assets by which people make a living [6]. These are spread across social, natural, financial, human, and physical assets and therefore the security of livelihoods is equally influenced by current conflicts.

The need to strengthen livelihoods has been recognised as being very necessary during conflicts and post conflicts period. Developing means to minimize the damage to livelihoods from conflicts is to this end a necessary strategy to complement conflicts effect. In Nigeria, smallholder agriculture continues to be the main economic activity that sustains the livelihoods of most farmers households. In the midst of conflicts, farmers' households and indeed the Taraba state food security seem threatened. It is a truism that farmers over the years have alternatively engaged in some form of livelihood supplements; however, it remains unclear as to the attributions of the recent intensification of the search for alternative livelihood activities among smallholder farmers [7].

Diversification, encompassing migration, nonfarm work, and social support networks, in addition to livestock production. Hunting and gathering of wild fruits, charcoal production, and chain saw operations are important coping strategies and a means of building assets that have become common [8, 9]. Armah et al. [10] include petty trading (sale of foodstuff, spices, dye clothing, and other basic household needs and equipment at community levels on table tops or small shops in communities or carried from community to community on head pans), craftsmanship, production of charcoal, and selling of firewood and emphasis that, people's livelihood depends on farming and other off-farm income generation activities. Most farmers usually migrate to more vibrant and economically productive areas to sell their labour. Demeke and Zeller [11] explain that when the rains are poor, farmers commit more labour resources to less risky alternative livelihood activities. Hence, sale of labour to off-farm livelihood activities lessens the effect of conflicts on household income and food supply.

Conflict in Taraba State threatens the livelihood resources of people particularly farming communities due to high dependent on natural resources for survival. Herder-farmer, inter-tribal and others conflicts not only have a direct impact on the lives and livelihoods of those involved, they also disrupt and threaten the sustainability of agricultural and pastoral production in the area and invariably the sustainability of livelihoods of the farming households. The frequent occurrence of conflict appears to have left adverse effects on livelihood of the farming households in the area. Conflicts no doubt have negative impact on social and economic development in Taraba State and Nigeria at large. The problem of this study is there to assess the Rural Farmers' Livelihood Security options amidst conflicts in Taraba State, Nigeria

Thus, the study aimed to:

- $\quad$ identify Farmers' Alternative Livelihood activities and

- $\quad$ analyse the determinants of livelihood diversification strategies among rural households.

\section{Methodology \\ The Study Area}

This study was conducted in Taraba State, Nigeria. Taraba State was formed out of the former Gongola State on the $27^{\text {th }}$ August, 1991. The State has 16 Local Government and Jalingo as its capital. Taraba State is situated in the North-eastern part of Nigeria, and it lies between Longitude 9030'E and 11045' $\mathrm{E}$ and Latitude 6025'N and 9030'. Taraba State shared border with plateau, Nasarawa and Benue State to the West, Adamawa and Gombe State to the North and to the East with republic of Cameroon. There are 73 spoken languages in Taraba State; the major languages are Wurkum, Jukun, Mumuye, Fulfulde, Kaka, Jonjo and Kona just to mention few. The State was named after the Taraba River which transverses the Southern part of the State. The mean annual rainfall shows a decrease from south to north $(100 \mathrm{~mm}-150 \mathrm{~mm})$. The raining season commences in April in the north to maximum of 200 days in the south. The dry season extends from October to early June and is marked by the hot north easterly harmattan. The population of Taraba State is 2,294, 800 people [2]. It has a land area of $54,428 \mathrm{~km}^{2}$. Agriculture is the major occupation of the people of the State employing over $70 \%$ of the total population. Cash crops produce in the State include coffee, tea, Groundnut and cotton. Crops such as maize, rice, sorghum, millet, cassava and yam are also produce in commercial quantity. Livestock production such as poultry, cow, goats, sheep and pig farming are fairly in large scale.

\section{Data Sources and Method of Collection}

Both primary and secondary data were used for this study. Primary data were collected from sample households using structured questionnaires and interview schedule

Multi-stage sampling procedure was adopted in the process of sample selection. The first stage was the purposive selection of Wukari, Ardo-kola and Takum LGAs base on the high incidence of farmer-herdsmen and tribal conflict as of 2017 to date out of the 16 LGAs in the state. The second stage involved the purposive selection of two farming communities in each Local Government Areas selected, where conflicts have occurred making a total of six villages. 
Thirdly, ten arable crop farmers were randomly selected from each village, thus giving a total of 84 farmers were selected for the quantitative data collection. A well-structured questionnaire was administered to 84 respondents, out of which 82 questionnaires were properly filled and returned. Analysis for this study was done based on the number of questionnaires retrieved.

\section{DATA ANALYSIS}

Descriptive statistics such as frequency, percentage and ranking and inferential statistics such as Logit regression was used to achieve objectives $\mathrm{i}$ and ii of the study respectively.

Logit regression model was used to determine the determinant of rural crop farmer's livelihoods. The probability of determinant of the rural crop farmers' livelihood determined by an underlying response variable that captures their true economic. The underlying response variable $\mathrm{y}^{*}$ in the case of binary choice is defined by the multivariate logit regression relation:

The relevant logistic expressions were given as:

$(y *=1)=1-F *\left(\Sigma X_{i} \beta_{j}\right)={ }_{e} \underline{\Sigma} X_{i} \underline{\beta}_{j}$

$$
1++_{e} \Sigma X_{i} \beta_{j}
$$

$(y *=0)=F *\left(\Sigma X_{i} \beta_{j}\right)=\underbrace{}_{1+{ }_{e} \Sigma X_{i} \beta_{j}} \ldots \ldots \ldots \ldots$

Where: $F=$ the cumulative distribution function for $\mu \mathrm{i}$,

The explicit logit model was expressed as:

$Y=\beta_{o}+\beta_{1} X_{1}+\beta_{2} X_{2}+$

$+\beta_{7} X_{7}+u$

Where;

$\mathrm{Y}=($ Livelihood diversified $=1$, not diversified $=0)$

$\beta_{1}-\beta_{8}=$ the coefficients for the respective variables in the logit function

$X_{1}=$ Age (years)

$X_{2}=$ Education (years of schooling)

$X_{3}=$ insecurity (yes $=1$, no $=0$ )

$\mathrm{X}_{4}=$ Farm size $(\mathrm{ha})$

$X_{5}=$ Reduced income from farming (

$X_{6}=$ Extension contact (yes $=1$, no $=0$ )

$\mathrm{X}_{7}=$ dependency households (number of persons)

$\mathrm{u}=$ error terms.

\section{Result ANd Discussion}

\section{Rural farmer's livelihood diversification Activities}

Alternative livelihood activities by farmers in the area varied and ranked in order of magnitude as can be seen in Table 1. These are basically aimed at diversifying the income sources of rural farmers, hence making them less vulnerable to the effect of conflicts in the area. The choice to engage in an alternative livelihood activities for most of the rural farmers in the Taraba State is influenced by current conflicts (famers-herders and inter-tribal conflicts) as majority (81.7\%) of respondents were into petty trading such as sale of cooked food, foodstuff, small household appliances and their accessories, and clothes among many others on table tops and stores while others carried these from one community to another on head pans. Its predominance was because it requires relatively less capital to commence as was also asserted by Mitullah [12]. The next highest alternative livelihood activity is casual daily labour $(62.2 \%)$, this is in line with the study of Tenaw [13] who revealed that daily laborer and contraband trading were alternative livelihoods activities. $54.9 \%$ were into food vending and $52.4 \%$ were Selling firewood/Charcoal production, meaning that abundance of trees suitable for charcoal production was found to be the prime driving force for the practice. Agyeman and Lurumuah [15] also confirm commercial charcoal production to be a major source of livelihood in the northern parts of Ghana. $50.0 \%$ were into hair dressing and $48.8 \%$ were engaged in selling local liquor as alternative livelihood activities due to conflict effects. This implies that to engage in alternative income generating activities explained that off-farm income generating activities in the study area have increased and have been skewed towards trading, casual daily labour, selling local liquor among others. According to Mengistu [15], major livelihood diversification activities were crop and livestock production, petty trading and remittance, making charcoal, wage and handcraft were livelihood diversification activities. This also collaborate with the study of Simbarashe [16] points out that Farmers have diversified into alternative livelihood activities such as firewood trade and brick moulding. 
Table-1: Farmers' Alternative Livelihood activities amidst conflicts

\begin{tabular}{|l|l|l|l|}
\hline Alternative Livelihood activities & Frequency & Percentage & Ranking \\
\hline Livestock rearing & 23 & 28.0 & $8^{\text {th }}$ \\
\hline Knitting & 18 & 22.0 & $9^{\text {th }}$ \\
\hline Petty trading & 67 & 81.7 & $1^{\text {st }}$ \\
\hline Tailoring & 31 & 37.8 & $7^{\text {th }}$ \\
\hline Hair dressing & 41 & 50.0 & $5^{\text {th }}$ \\
\hline Building & 14 & 17.1 & $11^{\text {th }}$ \\
\hline Casual daily labour & 51 & 62.2 & $2^{\text {nd }}$ \\
\hline Selling local liquor & 40 & 48.8 & $6^{\text {th }}$ \\
\hline Selling firewood/Charcoal production & 43 & 52.4 & $4^{\text {th }}$ \\
\hline Sale of firewood & 17 & 20.7 & $10^{\text {th }}$ \\
\hline Food vending & 45 & 54.9 & $3^{\text {rd }}$ \\
\hline Carpentry & 13 & 15.9 & $12^{\text {th }}$ \\
\hline Blacksmithing & 9 & 11.0 & $13^{\text {th }}$ \\
\hline Chainsaw operation & 8 & 9.8 & $14^{\text {th }}$ \\
\hline
\end{tabular}

\section{Determinants of Rural Farmers Livelihoods diversifications strategies amidst conflicts}

In determining the determinants of rural farmer's livelihood in the study area, the logit regression model comprising 7 independent variables were used as specified in the methodology. The result shows that six variables: level of formal education $((p<0.01)$, insecurity $(p<0.01)$, farm size $(p<0.01)$, reduced farm income $(p<0.05)$, extension contact $(p<0.01)$ and dependency households $(p<0.01$ ) were positive and significantly enhancing farmers choice of alternative livelihood diversification while age was negative and significant at 0.01 level.

The coefficient of age $(-0.53)$ meaning that age affect farmers decision to diversify livelihood strategy negatively and significantly at $1 \%$ level. This implies that if other factors are held constant, the probability of the household to choose livelihood strategies of the household decreases by a factor of $53 \%$ as the age of the household increases by 1 year. The possible reason is that elder farmers are well established and more experienced in agricultural production, more resistant to new ideas and information; they are more likely to be set in their ways and may not venture into new diversification activities. This finding is similar to that of Fikru [17].

The coefficient of years of education (0.08) was positive and significant, thus suggesting that educated person had better ability to diversify livelihood strategies since they may have better skill, experience and knowledge. Education level influenced positively the households' livelihood diversification [18, 15].

Insecurity was positively and statistically influenced households' choice of livelihood diversification strategy at $1 \%$ level of significance. The coefficient $(0.29)$ revealed that conflicts influences farmers' decision to partake in non-farm economic activities. meaning that if other factors remain constant, the decision of rural households to choose alternative livelihood diversification strategies increases by $29 \%$ as the farmers do not go to farm any more for fear of death/attack. This means rural households who were affected by conflicts be it farmers-herders or inter-tribal conflicts have more probability to diversifying their livelihood options into non-farm income activities.

The coefficient of farm size $(0.25)$ was positive and significantly influenced the probability of livelihood diversification option into non-farm activities at $1 \%$ probability level. The result shows that a unit decrease in farm size could result in increasing the probability of farmers' engagement in non-farm economic activities by about $25 \%$ holding other things constant. That means, farmers having less land size don't depend only on on-farm but they also go for non-farm in order to satisfy basic needs. Also, declining land size under population pressure which results to communal crisis may encourage rural households to diversify their sources of income. This opposed the study of Amogne et al. [19] and Sallawu et al. [13] who reported that farm size had negatively and significantly influenced the probability of livelihood diversification into non-farm activities at $10 \%$ probability level.

The coefficient of reduced farm income (0.49) was found to be positive and statistically significant at $5 \%$ level to the livelihood diversification strategies. This implies that households with less farm income as a result of conflicts have high probability of diversifying their livelihood choices into no-farm income activities amidst conflicts. If other factors remain constant, the farmer's choice of diversifying income activities increases by $49 \%$.

Access to extension services plays a significant role in improving and achieving the goal of agricultural and rural development goals. The coefficient of access to extension services (0.47) was found positive and statistically significant relationship $1 \%$ level. This implies that extension workers are not only providing agricultural extension services to farmers but also entrepreneurial skills, the entry point for participating in non-farm income business activities amidst conflict. This result is in contrary to the study of Gebru et al. [13] who reported that the estimated coefficient extension contact showed a negative and statistically significant 
relationship $(p<0.01$ and $p<0.05)$. However, other studies revealed that frequency of visit by development agents had positive impact on livelihood diversification [15].

The coefficient of Dependency households (0.37) was found to have positively influenced rural farmer's choices of livelihoods diversification options amidst conflicts at $1 \%$ level. Meaning that as households dependency ratio increases, the need to participate in off-farm and nonfarm income-generating livelihood diversification strategies also increase amidst conflicts. This opposes the study of Gebru et al. [20] who opined that the coefficient of dependency households (Dependant) was found to have negative relationship with choices of household livelihood diversification strategies and statistically significant at $5 \%$ probability level.

Table-2: Determinants of livelihood among rural farmers

\begin{tabular}{|c|c|c|c|c|}
\hline Variable & Coefficient & Std. Error & z-Statistic & Prob. \\
\hline Constant & 2.719488 & 2.522998 & 1.077880 & 0.0101 \\
\hline Age $\left(X_{1}\right)$ & -0.529775 & 0.534146 & -1.863965 & $0.0042^{* * *}$ \\
\hline Education level $\left(\mathrm{X}_{2}\right)$ & 0.078698 & 0.501311 & 0.156984 & $0.0013^{* * * *}$ \\
\hline Insecurity $\left(\mathrm{X}_{3}\right)$ & 0.285799 & 0.329986 & 0.866092 & $0.0004^{* * * *}$ \\
\hline Farm size $\left(X_{4}\right)$ & 0.245800 & 0.335877 & 0.731815 & $0.0103^{* * * *}$ \\
\hline Reduced income from farming $\left(X_{5}\right)$ & 0.491755 & 0.517102 & 0.950983 & $0.0516^{* \star}$ \\
\hline Extension contact $\left(\mathrm{X}_{6}\right)$ & 0.472918 & 0.547534 & 0.863723 & $0.0107^{\star * *}$ \\
\hline Dependency households $\left(X_{7}\right)$ & 0.366293 & 0.536946 & 0.682179 & $0.0121^{* * * *}$ \\
\hline
\end{tabular}

\section{Conclusion ANd ReCOMmEndATIONS}

The key finding of the study was that farmers in conflicts affected area use alternative livelihood activities to conserve livelihood security in the midst of conflicts. The primarily objective of the farming households was for survival. Majority of the households in the study area have unevenly diversified sources of income. They diversify their income sources into non-farm activities motivated by conflicts and low farm income. The study recommends the following:

- Government at all levels and nongovernmental organizations should give attention for rural livelihood improvement through providing security in the conflicts areas.

- Government efforts should focus on policy intervention mechanism that facilitates livelihood diversification in generating additional income sources for the rural farmers by expanding networks information, improve incentive and consultancy service on livelihood diversification opportunities to diversify agriculture-linked non-farm and off farm livelihood activities rather than focusing on the single agricultural productive farm to generate asset accumulation for rural poor amidst conflicts.

\section{REFERENCES}

1. Yamba, S., Appiah, D. O., Pokuaa-Siaw, L., \& Asante, F. (2017). Smallholder Farmers' Livelihood Security Options amidst Climate Variability and Change in Rural Ghana. Scientifica, 2017.

2. Selvaraju, R., Subbiah, A. R., Baas, S., \& Juergens, I. (2006). Livelihood adaptation to climate variability and change in droughtprone areas of Bangladesh: Developing institutions and options.

3. Aid, C. (2014). "Integrating Adaptation to Climate Change into Secure Livelihoods. An adaptation toolkit,"https://unfccc.int/ files/adaptation/application/pdf/christianaidap update sep 09 toolkit 7 sp.pdf.

4. Morse, S., \& McNamara, N. (2013). The theory behind the sustainable livelihood approach. In Sustainable Livelihood Approach (pp. 15-60). Springer, Dordrecht.

5. Ukamaka, D. M., Danjuma, S. E., Mbolle, C. J., Achonam, E. I., \& Mbadiwe, I. E. (2017). Livelihood issues in herdsmen-farmers conflict among farming communities in Kogi State, Nigeria. African Journal of Agricultural Research, 12(24), 2105-2115.

6. Elasha, B. O., Elhassan, N. G., Ahmed, H., \& Zakieldin, S. (2005). Sustainable livelihood approach for assessing community resilience to climate change: case studies from Sudan. Assessments of impacts and adaptations to climate change (AIACC) working paper, 17.

7. Akudugu, M. A., \& Alhassan, A. R. (2012). The climate change menace, food security, livelihoods and social safety in Northern Ghana. International Journal of Sustainable Development and World Policy, 1(3), 80-95.

8. Stanturf, J. A., Warren, M. L., Charnley, S., Polasky, S. C., Goodrick, S. L., Armah, F., \& Nyako, Y. A. (2011). Ghana climate change vulnerability and adaptation assessment. Washington: United States Agency for International Development.

9. Yaro, J. A. (2013). Building resilience and reducing vulnerability to climate change: Implications for food security in Ghana. Friedrich-Ebert-Stiftung, Ghana Office.

10. Osei-Owusu, Y., Al-Hassan, R., \& Doku-Marfo, E. (2012). Assessing the adaptation mechanisms of smallholder farmers to climate change and agro biodiversity losses in northern Ghana. Accra, START/Conservation Alliance, 1-359.

11. Demeke, A. B., \& Zeller, M. (2012). Weather risk and household participation in off-farm activities in rural Ethiopia. Quarterly Journal of International Agriculture, 51(892-2016-65160), 1-20. 
12. Mitullah, W. V. (2003). Street vending in African cities: A synthesis of empirical finding from Kenya, Cote d'Ivoire, Ghana, Zimbabwe, Uganda and South Africa.

13. Sallawu, H., Tanko, L., Nmadu, J. N., \& Ndanitsa, A. M. (2016). Determinants of income diversification among farm households in niger State, Nigeria. Russian Journal of Agricultural and Socio-Economic Sciences, 50(2).

14. Agyeman, K. O., Amponsah, O., Braimah, L., \& Lurumuah, S. (2012). Commercial charcoal production and sustainable community development of the upper west region, Ghana. Journal of Sustainable development, 5(4), 149.

15. Anshiso, D., \& Shiferaw, M. Determinants of Rural Livelihood Diversification: The Case of Rural Households in Lemmo District, Hadiyya Zone of Southern Ethiopia.

16. Gukurume, S. (2013). Climate change, variability and sustainable agriculture in Zimbabwe" s rural communities. Russian Journal of Agricultural and Socio-Economic Sciences, 14(2).

17. Fikru, T. (2008). A case study of non-farm rural livelihood diversification in Lume Woreda, Oromiya regional state. A Master of Arts Thesis in Development Studies. Addis Ababa University, Ethiopia.

18. Ahmed-Gamgum, W. A. (2018). Herdsmen and farmers conflict in Nigeria: Another dimension of insecurity. Journal of Public Administration and Social Welfare Research, 3(1), 35-62.

19. Asfaw, A., Simane, B., Hassen, A., \& Bantider, A. (2017). Determinants of non-farm livelihood diversification: evidence from rainfed-dependent smallholder farmers in northcentral Ethiopia (Woleka sub-basin). Development Studies Research, 4(1), 22-36.

20. Gebru, G. W., Ichoku, H. E., \& Phil-Eze, P. O. (2018). Determinants of livelihood diversification strategies in Eastern Tigray Region of Ethiopia. Agric \& Food Security, 7:62

21. Eshetu, S., Belete, B., \& Goshu, D. (2010). Income diversification through improved irrigation in Ethiopia: impacts, constraints and prospects for poverty reduction Evidence from East Harerghe Zone,Oromia Region, Ethiopia, RiPPLE, Addis Ababa, Ethiopia. 